\title{
Parameters Impact on Capital Formation and Key Suggestions for the Krishi Vigyan Kendra's in Nagaland
}

\author{
Imsunaro Jamir and Amod Sharma* \\ Department of Agricultural Economics, Nagaland University SASRD Medziphema Campus, \\ District: Dimapur - 797 106, Nagaland, India \\ *Corresponding author
}

\begin{tabular}{l} 
Key w or d s \\
KVK, Impact, Capital, \\
Formation, Parameter, \\
Selected \\
Article Info \\
$\begin{array}{l}\text { Accepted: } \\
22 \text { October } 2018 \\
\text { Available Online: } \\
10 \text { November } 2018\end{array}$ \\
\hline
\end{tabular}

\section{A B S T R A C T}

The present study on impact assessment of Krishi Vigyan Kendra (KVK) training programmes in Nagaland state was undertaken during the year 2012-13 to 2016-17 (five years) and to assess the impact of income as well as employment generated it was categorized into two groups viz., adopted and non-adopted villages ( 80 respondents to each category). To achieve the objectives of the present study a multi stage purpose random sampling methods was adopted. While for capital formation of the households different parameters was selected viz., human capital, physical capital, social capital, financial capital and food security all the five parameters were shown an increased in the total contribution, even overall capital formation were indicating to increase from 51.82 to 69.00 per cent after taking the different schemes, projects, training programmes implemented by both KVK's in the study areas. Substantially there were a decrease in the percentage of respondents in low and medium groups, which was due to the shifting these group towards the high capital formation groups, which shows positive impact and found to be statistically significant at 1 and 5 per cent level.

\section{Introduction}

Agriculture is one of the significant contributors to the Net State Domestic Product and is the largest employer of the working force in the state. Though the dependency of employment on agriculture has declined from as high as 96.50 per cent in the 1950 s to about 68.00 per cent in 2000 , it continues to be the main source of livelihood. Shifting and terraced cultivations remains the dominant forms of land use practice in the state. The traditional form of shifting cultivation i.e. jhum, is the method of cultivation that is widely practiced across Nagaland. Jhum occupies about 90.00 per cent of the area under agriculture. Terraced cultivation is confined largely to the districts of Kohima, Dimapur, Tuensang, Peren, Phek and Wokha. The single cropping system is prevalent in the state resulting in low cropping intensity. Multiple cropping is yet to be practiced by farmers except in very small and negligible pockets.

The effectiveness of the KVK was further enhanced by adding the activities related to on-farm testing and Front-Line Demonstration 
on major agricultural technologies in order to make the training of farmers location specific, need based and resource-oriented. The training programmes were designed to impart the latest knowledge to the farmers through work experience by applying the principles of 'Teaching by Doing' and 'Learning by Doing'. The prime goal of KVK is to impart training as per needs and requirements in agriculture and allied enterprises to all farmers, farm women and farm youths including school drop-outs in the rural area.

While designing the courses, the concept of farming system as well as farming situation are taken into account to ensure that the enterprises in which they are trained are commercially and ecologically viable, sustainable and profitable. Such vocational trainings help them to sustain themselves through self-employment and to make them self-reliant economically and thus discourages them to migrate to the urban areas. KVKs provide training not only in agriculture and allied vocations but also in other incomegenerating activities that may supplement the income of farm families. The methods employed in training could be formal and nonformal or a combination of both, depending upon the needs but emphasis remains to be on work-experience. The programmes of each KVK cover training, on-farm trials, frontline demonstrations, agricultural extension and livelihood activities. Keeping in view the above fact, the present study is undertaken, with the following two specific objectives viz; (i) to study the Impact of KVK's training in terms of capital formation, and (ii) to suggests the ways and means facing the constraints in disseminating knowledge by the KVK's.

\section{Materials and Methods}

The present study is to assess the impact of KVK for disseminating the agriculture technology to the farming community in
Nagaland state, which is working as per the guidelines of Central Government with the help of Ministry of Agriculture, Government of India. The sampling design and analytical techniques to be used in the light of objectives laid down for the study have been presented under the following sub-headings.

\section{Selection of districts}

The KVK was launched in 1988-89 in all 11 districts viz; Dimapur, Kohima, Kiphire, Longleng, Mokokchung, Mon, Phek, Peren, Tuensang, Wokha and Zunheboto of Nagaland, out of these districts two district viz; Mokokchung and Zunheboto districts of Nagaland have been selected because of the fact that it is expected to provide all the relevant information and hence can conveniently be obtained for conducting this study. The project area also has a good network of infrastructure and allied activities related to the scheme such as development agencies, nationalized banks, well-established marketing and communication facilities etc. Keeping all the above facts, both districts of Nagaland are therefore purposively selected to conduct this study.

\section{Selection of blocks}

Two blocks from each district will be selected randomly for the present study as these blocks are well covered by KVK programmes.

\section{Selection of villages}

Altogether eight villages were selected randomly from each district, while four villages from each block were selected and listed which would be obtained from the offices of SDO (Civil), R. D. block headquarter and other related offices. However, it is proposed to select four villages from each block randomly covered for KVK programme / schemes. 


\section{Selection of farmers}

After selection of the villages, a list of beneficiaries and non-beneficiaries of $\mathrm{KVK}$ will be prepared from each of the selected village. In order to have representative sample from each village a sample of 20 numbers of cases of KVK, out of that 10 from beneficiaries and 10 from non-beneficiaries will be drawn following the purposively random sampling method.

This will result in selection of 160 respondents from 8 villages, out of which 80 will be beneficiaries of KVK schemes and 80 will be non-beneficiaries of KVK schemes.

\section{Analytical techniques and tools}

Collected data will be scrutinized, tabulated and processed systematically according to the objectives laid down for the study.

Tabular and functional analysis will be used to meet the objectives of the study as and where needed, data were analysed by tabular presentation method where frequencies and percentages were used, mean, standard deviations were used to categorise the sample.

Impact index was used to find the extent of KVK's training / programme for adopted and non-adopted both groups. Frequency and percentage were used for tabular analysis. Mean and standard deviation were computed to categorize the respondents.

Paired ' $t$ ' test was used to know the significance of difference in Impact assessment before and after taking income generating activity. The chi-square analysis was used to find the association between different activities and socio-economic characteristics of respondents. Modified chisquare values were calculated for the data where cell frequencies were less than five.

\section{Results and Discussion}

The present results and discussion was collected from the selected KVK's adopted and non-adopted farmers. The data were analysed as per the requirement of the stated objectives.

Table 1 reveals the change in Overall formation factors due to the enhancement of income (Rs) and employment generation (manday). Data clearly indicates an increase from Overall Capital Worth on age (24.70 per cent), occupation (66.70 per cent), farm size (89.60 per cent), social participation (32.50 per cent), mass media (85.30 per cent), economic motivation (61.00 per cent), Credit facilities (72.50 per cent), farming experience (73.20 per cent), technology (71.20 per cent), annual income $(91.10$ per cent $)$ and employment ( 82.70 per cent). All the variables were found to be significant at 1 per cent level of significance. Even the extension contact (14.90 per cent) was found to be significant at 5 per cent level of significance. Education ( 9.40 per cent) was found to be non-significant but positive, whereas the family size $(-24.70$ per cent) was found to be negative significant at 1 per cent level of significance which is an indication of negative correlation / reverse impact due to the large /big family size to gain better income / employment based training / programme conducted by the KVK's in the study area. As per Human Capital (HC) aspect, before it was 47.50 per cent and after getting programme / training it has increased up to 71.25 per cent, which was found to be significant at 1 per cent level of significance. On Physical Capital (PC) aspect, before it was 48.75 per cent and after getting programme / training it has increase up to 62.50 per cent which was found to be significant at 1 per cent level of significance.

Table 1 reveals that the human capital for age (23.60 per cent), occupation (62.70 per cent), 
farm size (85.60 per cent), social participation (30.20 per cent), mass media (81.60 per cent), extension contact (18.40 per cent), economic motivation (56.20 per cent), Credit facilities (66.00 per cent), farming experience (67.50 per cent), technology (66.80 per cent), annual income (88.40 per cent) and employment (77.70 per cent). All the above variables were found to be significant at 1 per cent level of significance. However, education (10.40 per cent) was found to be non-significant but positive whereas, the family size $(-22.60$ per cent) was found to be negative significant at 1 per cent level of significance.

Further data reveals the physical capital for occupation (57.40 per cent), farm size (71.10 per cent), social participation (23.10 per cent), mass media (69.40 per cent), economic motivation (49.60 per cent), Credit facilities (60.90 per cent), farming experience (60.70 per cent), technology (56.70 per cent), annual income (75.60 per cent) and employment (81.30 per cent). All the variables were found to be significant at 1 per cent level of significance and both age (14.30 per cent) and extension contact ( 2.22 per cent) were found to be significant at 5 per cent level of significance; while the education (10.40 per cent) was found to be non-significant but positive. The family size ( -22.60 per cent) was found to be negative significant at 1 per cent level of significance.

Table further reveals the social capital for age (23.60 per cent), occupation (62.70 per cent), farm size (85.60 per cent), social participation (30.20 per cent), mass media (81.60 per cent), extension contact (18.40 per cent), economic motivation (56.20 per cent), Credit facilities (66.00 per cent), farming experience (67.50 per cent), technology (66.80 per cent), annual income (88.40 per cent) and employment (77.70 per cent). All the above variables were found to be significant at 1 per cent level of significance. However, education (10.40 per cent) was found to be non-significant but positive and family size (-22.60 per cent) was found to be negative significant at 1 per cent level of significance.

Table further reveals the financial capital for the age (22.20 per cent), occupation (62.50 per cent), farm size (84.00 per cent),social participation (33.70 per cent), mass media (78.40 per cent), economic motivation (62.30 per cent), Credit facilities (73.90 per cent), farming experience (72.40 per cent), technology (67.50 per cent), annual income (79.80 per cent) and employment (70.30 per cent). All the above variables were found to be significant at 1 per cent level of significance. Extension contact $(11.90$ per cent $)$ and education (12.00 per cent) both were found to be non-significant but positive whereas, the family size ( -24.60 per cent) was found to be negative significant at 1 per cent level of significance.

Table further reveals the Food Security for the age (28.40 per cent), occupation (62.00 per cent), farm size (85.00 per cent), social participation (32.00 per cent), mass media (80.60 per cent), economic motivation (56.90 per cent), credit facilities (68.00 per cent), farming experience (69.40 per cent), technology (69.00 per cent), annual income (85.90 per cent) and employment (74.60 per cent). All the above variables were found to be significant at 1 per cent level of significance. Extension contact ( 15.10 per cent) was found to be significant at 5 per cent level of significance, while education (7.10 per cent) was found to be non-significant but positive. However, family size (-22.60 per cent) was found to be negative significant at 1 per cent level of significance.

On other functioning of the KVK's training / programmes, 3 (1.88 per cent) have ideas and responses which is of non-adopted KVK's respondents only. 
Table.1 Relationship with independent variable with capital formation factors

\begin{tabular}{|c|l|c|c|c|c|c|c|}
\hline S. N. & Independent variables & HC & PC & SC & FC & FS & Overall \\
\hline 1. & Age & $0.236^{* *}$ & $0.143^{*}$ & $0.236^{* *}$ & $0.222^{* *}$ & $0.284^{* *}$ & $0.247^{* *}$ \\
\hline 2. & Education & $0.104^{\mathrm{NS}}$ & $0.031^{\mathrm{NS}}$ & $0.104^{\mathrm{NS}}$ & $0.120^{\mathrm{NS}}$ & $0.071^{\mathrm{NS}}$ & $0.094^{\mathrm{NS}}$ \\
\hline 3. & Occupation & $0.627^{* *}$ & $0.574^{* *}$ & $0.627^{* *}$ & $0.625^{* *}$ & $0.620^{* *}$ & $0.667^{* *}$ \\
\hline 4. & Farm size & $0.856^{* *}$ & $0.710^{* *}$ & $0.856^{* *}$ & $0.840^{* *}$ & $0.850^{* *}$ & $0.896^{* *}$ \\
\hline 5. & Family size & $-0.226^{* *}$ & $-0.123^{\mathrm{NS}}$ & $-0.226^{* *}$ & $-0.246^{* *}$ & $-0.226^{* *}$ & $-0.223^{* *}$ \\
\hline 6. & Social participation & $0.302^{* *}$ & $0.231^{* *}$ & $0.302^{* *}$ & $0.337^{* *}$ & $0.320^{* *}$ & $0.325^{* *}$ \\
\hline 7. & Mass media & $0.816^{* *}$ & $0.694^{* *}$ & $0.816^{* *}$ & $0.784^{* *}$ & $0.806^{* *}$ & $0.853^{* *}$ \\
\hline 8. & Extension contact & $0.184^{* *}$ & $0.022^{\mathrm{NS}}$ & $0.184^{* *}$ & $0.119^{\mathrm{NS}}$ & $0.151^{*}$ & $0.149^{*}$ \\
\hline 9. & Economic motivation & $0.562^{* *}$ & $0.496^{* *}$ & $0.562^{* *}$ & $0.623^{* *}$ & $0.569^{* *}$ & $0.610^{* *}$ \\
\hline 10. & Credit facilities & $0.660^{* *}$ & $0.609^{* *}$ & $0.660^{* *}$ & $0.739^{* *}$ & $0.680^{* *}$ & $0.725^{* *}$ \\
\hline 11. & Farming experience & $0.675^{* *}$ & $0.607^{* *}$ & $0.675^{* *}$ & $0.724^{* *}$ & $0.694^{* *}$ & $0.732^{* *}$ \\
\hline 12. & Technology & $0.668^{* *}$ & $0.567^{* *}$ & $0.668^{* *}$ & $0.675^{* *}$ & $0.690^{* *}$ & $0.712^{* *}$ \\
\hline 13. & Annual income & $0.884^{* *}$ & $0.756^{* *}$ & $0.884^{* *}$ & $0.798^{* * *}$ & $0.859^{* *}$ & $0.911^{* *}$ \\
\hline 14. & Employment & $0.777^{* *}$ & $0.813^{* *}$ & $0.777^{* *}$ & $0.703^{* *}$ & $0.746^{* *}$ & $0.827^{* *}$ \\
\hline
\end{tabular}

$(* * \& *$ Significant at $1 \& 5$ per cent level of significant, NS: Non-significant)

Table.2 Suggestion given by adopted villages for the KVK's in the study area

\begin{tabular}{|c|c|c|c|c|}
\hline S. No. & Suggestions & Number & Percentage & Rank \\
\hline 1. & Training programme conducted at block level & 68 & 85.00 & I \\
\hline 2. & KVK office release improved variety & 67 & 83.75 & II \\
\hline 3. & Production technology given in time & 65 & 81.25 & III \\
\hline 4. & Financial facilities given in time & 62 & 77.50 & IV \\
\hline 5. & Government assistance within time frame & 58 & 72.50 & V \\
\hline 6. & Farmers should maintain their land holding & 58 & 72.50 & $\mathbf{V}$ \\
\hline 7. & Training centre / institutes at block level & 56 & 70.00 & VI \\
\hline 8. & Need based training may be given & 54 & 67.50 & VII \\
\hline 9. & Irrigation sources should be increased & 52 & 65.00 & VIII \\
\hline 10. & Efforts should be made of irrigation water & 50 & 62.50 & IX \\
\hline 11. & Roads and transport facilities to be improved & 45 & 56.25 & $\mathbf{X}$ \\
\hline 12. & Government livelihood activity encouraged & 45 & 56.25 & $\mathbf{X}$ \\
\hline 13. & Skill based training programmes encouraged & 43 & 53.75 & XI \\
\hline 14. & Success story / case study must be encouraged & 38 & 47.50 & XII \\
\hline 15. & Mechanization must be encouraged & 36 & 45.00 & XIII \\
\hline 16. & Documentation should be strong & 32 & 40.00 & XIV \\
\hline 17. & Locally made commodity should be encouraged & 32 & 40.00 & XIV \\
\hline 18. & Post-harvest management should be encouraged & 28 & 35.00 & XV \\
\hline 19. & Information centre should be established & 23 & 28.75 & XVI \\
\hline 20. & Saving habit should be encouraged & 21 & 26.25 & XVII \\
\hline 21. & Metrological station should be established & 18 & 22.50 & XVIII \\
\hline
\end{tabular}


On N/A functioning of the KVK's training / programmes, 2 (1.25 per cent) have ideas and responses which is of non-adopted KVK's respondents.

Further the KVK's also provide the training / activities on the following aspects but due to lack of data base it was difficult to record all those but in coming days it will be covered:

\section{Backward linkage}

Seed supply status

Seed certification facilities

Fertilizer

Machine and tools facilities

Credit facilities

Labour status

\section{Forward linkage}

Manure status

Storage facilities

Transportation facilities

Agro-based industries

Labour status.

Table 2 an attempt is made to identify the ssuggestions given by adopted villages for the KVK's in the study area for making the training / programme more effective for implementing the schemes in the KVK's adopted villages which are presented in the table shown with frequency and simple percentage and then it has been ranked using the Garrett's ranking technique. The analytical findings has been found almost similar across various farm size groups so it was recorded as overall / average views of the respondents. Therefore, the suggestions are not discussed according to different size group of farmers, rather the sample farmer as a whole.

Among suggestions, the foremost is that, training programme may be conducted at block levelby 68 ( 85.00 per cent) in the study area, then the second highest by 67 ( 83.75 per cent) who are in the view that the KVK office release improved variety deemed fit to the local areas, the production technology given in time by 65 (81.25 per cent) as third suggestions, while the forth suggestion is, financial facilities must be given in time by 62 (77.50 per cent) and the fifth suggestion by 58 (72.50 per cent) for government assistance within time frame and farmers should maintain their land holdings respectively.

The sixth suggestion was based on the training centre / institutes which must be at block level by 56 (70.00 per cent) in the study area, 54 (67.50 per cent) felt that the KVK office must provide need based training not as per the Central / State Government directives,

Instead it should be need based and useful as seventh suggestion, further eighth suggestion is by 52 (65.00 per cent) respondents who feltthe need / importance of irrigation sources so as to achieve the goal of doubling the farmers income by Central government and the ninth suggestions is given by $50(62.50$ per cent) who suggested that efforts (investment)must be encouraged for the irrigation water facilities and the tenth suggestion by 45 (56.25 per cent) for improving the road conditions and transport facilities so as to encourage livelihood activity respectively.

The eleventh suggestion is to develop the skill based training programmes by 43 (53.75 per cent) respondents, twelfth suggestions is to encourage the success story / case study by 38 (47.50 per cent) while, mechanization to be encouraged by 36 (45.00 per cent) asthe thirteenth suggestions and by 32 (40.00 per cent) as fourteen suggestion for documentation to be strong followed by locally made commodity to be encouraged for getting good livelihood activity respectively. 
The fifteen suggestions is to develop the postharvest management by 28 (35.00 per cent), the sixteen suggestion given by 23 (28.75 per cent) felt that information centre should be established at block level to provide the information in time related to agriculture and allied activities to the concern household for improving the efficiency and utility, further seventeen suggestion is given by 21 (26.25 per cent)as savings to be encouraged and the last eighteen suggestion is given by $18(22.50$ per cent)that the metrological station should be established at block / district level due to climatic effect on the production and productivity respectively.

From the present study the main conclusions emerge as per the study entitled was the parameters for overall capital formation in terms of income and employment include Human Capital (HC), Physical Capital (PC), Social Capital (SC), Financial Capital (FC) and Food Security (FS). After KVK training programmes, it has increased up to 69.00 per cent which was found to be significant at 1 per cent level of significance of paired ' $t$ ' test indicating a positive impact on income and employment.

\section{References}

Analogous. 2017. Statistical Hand of Nagaland Published by Directorate of Economics and Statistics (various issues), Kohima, Nagaland.

Pongener, Bendangjungla. and Sharma, Amod. 2018. Constraints Faced by the Fishery Enterprises: A SWOC Analysis. IJCMAS. 7(5). May: 1595-1603.

Sangtam, Likhase. L. T. and Sharma, Amod. 2015. Impact of Bank Finance on Employment and Income through Piggery Enterprise in Nagaland. EPRAIJEBR. 3(11). Nov: 273-276.

Sharma, A. 2002. Source and Knowledge on beneficiaries about the purpose of credit
- A case study of Agra Region of Uttar Pradesh. Journal of Interacademica. 6(3). July: 374-379.

Sharma, A. 2004. Constraints of Fish Production - A case study in rainfed areas of Uttar Pradesh. Journal of Interacademica. 8(4). October: 639643.

Sharma, A. and Sharma, Anamika. 2008. Problems faced by the farmers in adoption of improved maize cultivation practices in hills. TJRAR. 8(2): 22-23.

Sharma, Amod. 2011. Economic and Constraints of King Chilli Growers in Dimapur District of Nagaland. Journal of Interacademicia. 15(4): 710-719.

Sharma, Amod. 2012. Inter-state Disparities in Socio-economic Development in North East Region of India. Journal of Agricultural Science. 4(9). September: 236-243.

Sharma, Amod. 2014. Sustainable economic analysis and extent of satisfaction level of King Chilli growers in Nagaland. Agriculture for Sustainable Development. 2(1). June: 188-191.

Sharma, Amod.; Kichu, Yimkumba. and Chaturvedi, B. K. 2016. Economics and Constraints of Pineapple Cultivation in Dimapur District of Nagaland. TJRAR. 16(1). January: 72-75.

Sharma, Amod.; Kichu, Yimkumba. and Sharma, Pradeep. Kumar. 2018. Sustainable economic analysis and constraints faced by the pineapple growers in Nagaland. Progressive Agriculture. 18(1). February: 27-33.

Shuya, Keviu. and Sharma, Amod. 2014. Impact and constraints faced by the borrowers of cooperative bank finance in Nagaland. Economic Affairs. 59(4). October: 561-567.

Shuya, Keviu. and Sharma, Amod. 2018. Problems faced by the Borrowers in Utilization and Acquiring of 
Cooperative Bank Loans in Nagaland. IJED. 14(2). April-June: 52-56.

Tangjang, Avicha. and Sharma, Amod. 2018. Problem faced by the Large Cardamom Growers during production and marketing: A case study of Tirap district of Arunachal Pradesh. IJCMAS. 7(5). May: 2561-2573.

Walling, Imti. and Sharma, Amod. 2015. Impact of SGRY on beneficiaries and non-beneficiaries in Dimapur district of Nagaland. TJRAR. 15(2). August: 9094.

Walling, Imti.; Sharma, Amod.; Yadav, Mukesh. Kumar.; Rajbhar, Arun, Kumar. and Kalai, Kankabati. 2017. Impact of Agricultural Technology Management Agency on Rural Economy of Nagaland, India. Plant Archiver. 17(2). October: 1511-1516.

\section{How to cite this article:}

Imsunaro Jamir and Amod Sharma. 2018. Parameters Impact on Capital Formation and Key Suggestions for the Krishi Vigyan Kendra's in Nagaland. Int.J.Curr.Microbiol.App.Sci. 7(11): 2679-2686. doi: https://doi.org/10.20546/ijcmas.2018.711.306 